Joseph Chamberlain and the Birmingham Town Council, $1865-1880$

Leslie Rosenthal

September 2015 


\section{Joseph Chamberlain and the Birmingham Town Council, 1865-1880}

Over the period 1865-1880, a group of modernising reformers gained control of the town council of Victorian Birmingham, England's second city, and, with this takeover, began a transformation of the town itself. At the centre of this reforming coterie was the imposing and charismatic figure of Joseph Chamberlain (1836-1914). With Birmingham as his power base, Chamberlain was to rise nationally, to become a hugely influential figure, ${ }^{1}$ remaining for over thirty years at the heights of political life in Britain. Within Birmingham itself, Chamberlain's circle was able to claim responsibility for fundamental changes to the physical structure of the town but also, and crucially, to change the very way local governance in Britain was viewed and exercised. Chamberlain could not have wrought such an impact without wide support on Birmingham's town council, but while the social make-up of the members of the town council in general over this period has previously received attention ${ }^{2}$, beyond a handful of his very closest and most prominent associates, the identity and even extent of Chamberlain's council allies, in particular, remains mostly unexplored. Extending research into Chamberlain's wider support base on council has motivated the analysis below.

The newly formed party organisation of the local Birmingham Liberal Association after 1865 is normally cited as the machine through which Chamberlain was able to dominate

\footnotetext{
${ }^{1}$ Chamberlain's life has attracted numerous biographers: Alexander Mackintosh Joseph Chamberlain; an Honest Biography, (Hodder \& Syoughton, 1914); James L. Garvin and Julian Amery The Life of Joseph Chamberlain, six volumes, (Macmillan, 1932-1969); Peter Fraser, Joseph Chamberlain:Radicalism and Empire,1868-1914,(Cassell, 1966); J. Enoch Powell, Joseph Chamberlain (Thames \& Hudson, 1977); Denis Judd, Radical Joe: A Life of Joseph Chamberlain, (Hamish Hamilton, 1977); Richard Jay, Joseph Chamberlain: A Political Study (Oxford University Press,1981); Peter T. Marsh Joseph Chamberlain: Entrepreneurin Politics (Yale University Press, 1994); Travis L. Crosby, Joseph Chamberlain: A Most Radical Imperialist (I.B.Tauris, 2011).

${ }^{2}$ Membership was notably entrepreneurial in occupation and non-conformist in belief, as is evident in the Appendix. See E. Peter Hennock, Fit and Proper Persons: Ideal and Reality in Nineteenth-Century Urban Government (Edward Arnold, 1973); Linda J. Jones 'Public Pursuit of Private Profit? Liberal Businessmen and Municipal Politics in Birmingham 1865-1900’, Business History, 25, 3, 1983 pp 240-59.
} 
Birmingham's political scene, but the Liberal party label and Association membership is unreliable and even misleading in identifying Chamberlain's friends and foes, as is demonstrated here: some of Chamberlain's bitterest foes were also Liberals, and some of his close supporters were Conservatives.

Birmingham, at the time, as its awesome economic power developed and it became England's second largest city, has numerous claims within social and political history that allow it to stand out among its fellow provincial towns and cities. It was in Birmingham that the national pressure group working for compulsory and universal schooling of children in Britain was founded (Birmingham Educational League, 1867, National Education League, 1869). It was in Birmingham that locally based, permanent and organised political party machines first emerged (Birmingham Liberal Association, 1865). It was in Birmingham that the municipalisation of local gas and water utility provision, so-called "gas-and-water socialism", was, if not initiated, then widely popularised (1874-6). Further, it was in Birmingham that the ideas and philosophy of the "civic/municipal gospel" were most obviously preached and celebrated ${ }^{3}$. This doctrine, encouraged, it is normally argued, by nonconformist Christian-social teachings, required local government to take a leading role in the social, physical and moral (no less) transformation of urban society. It can be no coincidence that Birmingham in this period saw the first locally organised (Liberal) party political machine, in control of electoral and political matters from street and municipality level up to Parliamentary constituency.

\footnotetext{
${ }^{3}$ Asa Briggs (1952) History of Birmingham, Vol 2 (1952, Oxford University Press); Derek Fraser, Power and Authority in the Victorian City, (1979, Basil Blackwell), pp101-4; Tristram Hunt, Building Jerusalem: the Rise and Fall of the Victorian City (2005, Phoenix) pp 313-359; Andy Green, 'The Anarchy of Empire: Reimagining Birmingham's Civic Gospel', Midland History, Vol. 36 No. 2, (Autumn, 2011), 163-79; Denys Leighton, 'Municipal Progress, Democracy And Radical Identity In Birmingham, 1838-1886', Midland History, Vol. 25, No 1 (June 2000), pp. 115-142.
} 
In the histories of all these Birmingham-centred phenomena the name of Joseph Chamberlain invariably appears prominently. Following a successful career as a brass-screw-making industrialist, Chamberlain had, by 1867, turned his attention to educational reform, pushing for state and locally funded universal and compulsory elementary schooling, and then to more general political issues. Chamberlain was first returned for the Birmingham town council in November 1869, and as soon as November 1873 he became mayor, retaining the mayoralty for $1874 / 5$ and $1875 / 6$. During this time, Chamberlain headed the process which municipalised Birmingham's local water and gas companies, plotted the destruction of the town's central slum district and replacement by a new grand commercial redevelopment (the Birmingham Improvement Scheme), paved the streets, re-sewered the town, and initiated the provision of civic spaces, libraries, schools and public baths. In 1876, he became one of Birmingham's three Members of Parliament. The changes instituted in the town transformed Birmingham into a beacon and exemplar for urban reform by other cities at this time. Bunce provides a contemporary paean for the transformation achieved for Birmingham:
All that was then wanting is now provided: public buildings, parks ... baths, libraries, educational institutions, common schools; the streets are thoroughly drained, perfectly kept, and well lighted ... and the pebble pavements ... are replaced with stone or asphalte (sic) or brick; the wretched mid den system has well nigh disappeared, and intelligent and cleanly methods of dealing with excreta have been substituted forit; the sewage no longer pollutes the streams but is employed to fertilise the land; courts and houses are carefully inspected, with the consequent removal of causes of diseases; the gas, cheapened to the lowest point, is in the hands of the Corporation; and the water supply ... is constant and unrestricted, alike to the poorest as to the wealthiest dwellings in the town. ${ }^{4}$

At this local urban micro-political level, and with Birmingham firmly in mind, Chamberlain at this time can be seen as a radical, (if top-down) modernising politician, quite a member of the contemporary liberal-democratic left, eager for change, improvement and reform.

\footnotetext{
${ }^{4}$ John T. Bunce, History of the Corporation of Birmingham, Vol. 2, (1885, Cornish Brothers, p xxvii).
} 
Chamberlain's later Parliamentary political career, as MP and cabinet minister, lies beyond our immediate scope, but his stances on Irish Home Rule, the Boer War, Empire tariff preference and the "histrionic jingo imperialism", attributed to many of his associates, take him out of sympathy with today's fashion. In 1886, Chamberlain was prominent as one of the instigators who split the Liberal Party into two diverging parts over William Gladstone's policies backing Irish Home Rule. Separating from the rump "Gladstonian" Liberals, Chamberlain helped form a new breakaway Liberal Unionist Party which, at times, commanded a formidable parliamentary bloc of around seventy seats ${ }^{6}$. Eventually, from 1895, the Liberal Unionists formally joined forces with the Conservatives, but Chamberlain then proceeded after 1902, in effect, to split the merged Conservative-Unionist party, this time over proposals concerning imperial trade policy and tariff reform. Serious ill-health intervened in 1906, when he was 70, and Chamberlain died in 1914.

Chamberlain's connections with Birmingham remained rock solid as his national profile rose. He remained on the town council as alderman until 1879 and a Birmingham MP until his death. In the 1886 General Election, Chamberlain's breakaway Liberal Unionists were returned for five of Birmingham's then seven parliamentary constituencies. On the town council in particular, Joseph's brother Richard quickly followed him (as councillor, alderman and mayor); as did various in-laws, cousins and personal friends among the closely intermarried Chamberlain, Kenrick, and Martineau families that for decades dominated Birmingham local politics. His close Birmingham-based colleagues Jesse Collings, William Kenrick and Joseph Powell Williams all followed Joseph into Parliament, as did brother Richard and both of Joseph's sons, Austin (1863-1937), who rose to be Chancellor of the Exchequer, and Neville (1869-1940), Prime Minister from 1937 to 1940.

\footnotetext{
${ }_{6}^{5}$ Jay (1981), p328.

${ }^{6}$ Ian Cawood, The Liberal Unionist Party: A History, (2012, I.B.Tauris).
} 
The success in transforming Birmingham attributed to Chamberlain was not and could not, of course, have been achieved by him alone. A loyal and like-minded group was required on the town council that supported his leadership, policies and ideas. The central research focus of this paper is the analysis of the establishment, membership and growing centrality of Chamberlain's group of reliable allies on the Birmingham town council over the period 18651880.

\section{Birmingham Town Council}

The Charter of Incorporation that established the authority of the municipal borough and town council of Birmingham dates back to October 1838. The town's local electoral wards were required to fill forty-eight seats on the Birmingham town council, elected by the eligible burgesses of the borough. Originally, ten wards annually returned one councillor each and three returned two but in 1873 an overdue rearrangement created sixteen wards, each returning a single councillor annually. Each councillor was to serve for three years, one-third retiring annually in November (possibly to be re-nominated). In addition, sixteen aldermen, who each served a six-year spell, were to be chosen from among these to complete the council. From the total of 64 members, a mayor would also be selected annually.

The voting system and voting eligibility for municipal elections changed fundamentally over the relevant period. Electoral reform substantially increased the total of eligible voters for Birmingham's annual municipal elections from around 9,500 in 1861, to about 48,000 in 1869 , and then, in 1880 , to about 74,600 (including around 10,000 women not enfranchised for parliamentary elections). The secret ballot, only introduced in 1872, also changed the style typical of English elections and helped increase the small number of contested ward elections.

For the period from around 1850 up to the late 1860 s, Birmingham local town council polity is usually characterised as experiencing a time of torpidity and inaction, and described as 
being directed by a group whose "ideas of local government were embodied in the one desire to keep down the rates" 7 . This straightforward rates-minimising policy was the major aim of the then-dominant if informal grouping of town council members calling themselves the "economy party" or "economists" and sometimes known as the "Woodmen" after the Woodman Inn on Easy Row (demolished in 1964) used for meetings by this group: the economy party imaginatively labelled their opponents on the council the "extravagant party". There is no reliable or even informal list of the individual members of the economy party, but this group was, indisputably, led and motivated, up to 1860 , by an extraordinary character, Joseph Allday ${ }^{8}$ (1798-1861) and backed by Allday's ragbag collection of ward-based Ratepayer Protection Associations. Allday first came to prominence and notoriety in Birmingham in the 1830s as proprietor of The Argus, a political journal described as scurrilous, "ultra-Tory" and a "receptacle of rancour, spite and calumny" 9 . Libel and assault charges were brought against Allday, for which he served a prison term and he ultimately withdrew from journalism. Still, subsequently, while a Poor Law Guardian, he investigated and publicised abuse and corruption scandals within the local penal system and Allday was returned as town councillor in 1849 , becoming an alderman and an influential chairman of the important Finance Committee ${ }^{10}$. His influence on the council was to persist well after his death in 1861.

Outside parliamentary contests, formal locally-affiliated organisations of the two traditional national political parties of the day were rare until the late $1860 \mathrm{~s}^{11}$, and until that time the labels "Liberal" and "Conservative" (or "Whig" and "Tory") remain mostly absent in contemporary descriptions of municipal affairs. Only at Birmingham's municipal elections of

\footnotetext{
${ }^{7}$ Bunce (1885, p xxxii).

${ }^{8}$ Richard Ward 'Joseph Allday: Scapegoat for Municipal Backwardness', Birmingham Historian, 32, 2008.

${ }^{9}$ Thomas T. Harman and Walter Showell, Showells Dictionary of Birmingham (1885, Cornish Bros).

${ }^{10}$ Birmingham Daily Post (hereafter BDP), Oct 14 1861, Oct 19 1861, an unbending supporter of Chamberlain's policies.

${ }^{11}$ Mois ei Ostrogorski, Democracy and the Organization of Political Parties, Vol I, (1902, Macmillan, pp 1612).
} 
the early 1870s do such labels begin to be applied: for example, in 1870, the Birmingham Daily Post began to attribute party labels during municipal elections for which the "propriety" of this innovation was strongly questioned ${ }^{12}$. The catalyst for this change was the 1867 Electoral Reform Act and the expansion of the electoral franchise.

\section{Liberals and the Liberal Caucus in Birmingham}

Before the 1867 Reform Act, Birmingham was a single parliamentary constituency which returned two MPs, each eligible voter having two votes. Following the Act, Birmingham (alongside Manchester, Leeds and Liverpool) had to return three MPs, but voters were still restricted to only two votes each. Unless the Liberals properly organised themselves, this might lead to a pile-up of "wasted" votes for two relatively popular Liberal candidates, potentially allowing a Conservative to creep in and steal the newly awarded third seat, reputedly the reason this odd restriction was applied. Birmingham had only ever once previously elected a Tory MP.

The Liberal faction in Birmingham reacted by organising the newly-formed Birmingham Liberal Association into what is considered Britain's first local-based political machine, often called the Birmingham Liberal Caucus. The Birmingham Liberal Association had only recently been founded, in February 1865, at a seventy-strong meeting in Birmingham's Town Hall $^{13}$; before this, as the meeting was told, there had been no formal organisation of the Liberal Party in Birmingham. The aims of the Association, as moved at that inaugural session, would be threefold: (a) to maintain Liberal MPs in representing the Birmingham borough; (b) to assist in the return of Liberal members for the surrounding Warwickshire county, and; (c) to promote Liberalism in government: all these original aims were directed at parliamentary objectives, municipal aspects were ignored. William Harris, briefly a

\footnotetext{
12 BDP, 2 Nov 1870.

13 BDP, 18 Feb 1865.
} 
councillor, became secretary of the Association and along with his successor, Francis Schnadhorst (even more briefly also a councillor), instituted the changes through which this local political machine was to evolve so successfully into the 1870 s. The Birmingham Liberal Association acquired a complicated pyramidal structure, overseen by a small Management Committee, which, designedly or not, Chamberlain and his allies were more than capable of exploiting ${ }^{14}$. Sometimes known as the "Six Hundred", after the number of posts involved in the pyramid, crucially, the system at its base rested upon individual municipal wards each having their own ward-level Liberal Association. In pursuit of its first aim, the Association would ensure the election of three Liberals within the new three-member-two-vote Birmingham multi-member constituency by telling the members and supporters of each ward Liberal association which combination of two of the three Liberal candidates to vote for. Liberal support would be evenly spread over the three Liberal candidates to minimise the chances that other parties could steal a seat: the "vote as you are told" system. Three Liberals were duly elected at the 1868 General Election.

Once the machine was operating after 1868, there then existed a formal Liberal party presence in every ward, available to organise for the annual municipal elections and to motivate the continuous year-by-year interest and activity of grass-roots, street-level Liberal support in Birmingham. The emergence of the familiar Liberal versus Conservative labels, previously largely absent within the wards and on the town council, followed.

\section{Chamberlain's Friends and Chamberlain's Foes}

“... as the sea is salt everywhere, so Birmingham is Liberal wherever you test it" John Bright MP $^{15}$

Joseph Chamberlain was on Birmingham's town council for a decade, after first being returned for St Paul's ward in November 1869, through his three-term spell as mayor from

\footnotetext{
${ }^{14}$ Ostrogorski, 1902, pp 166-7.

${ }^{15}$ BDP 2 Nov 1875
} 
November 1873, until May 1879. Despite John Bright's belief, it was not true that Liberals totally monopolised the local polity: and Chamberlain could not even count upon those labelled as Liberals on council to support the political program that he would put in place. For Birmingham at this time, party label, even when displayed, is an unreliable guide to Chamberlain's potential allies on the town council.

Some of Chamberlain's supporters on council are well-known from biographical detail, notably those among the blood relatives and in-laws of the Chamberlain ${ }^{16}$, Kenrick $^{17}$ and Martineau $^{18}$ families, an intimate extended clan of mutual support. Fellow members on council alongside Joseph Chamberlain were: Joseph's brothers Arthur Chamberlain and Richard Chamberlain; Joseph's brothers-in-law William Kenrick and Thomas Martineau; and Robert Francis Martineau, brother to Thomas Martineau. The Kenricks and the Chamberlains were intermarried to an extraordinary degree: Joseph Chamberlain's first two wives, Florence Kenrick and Harriet Kenrick, both of whom died tragically young, were themselves first cousins; Joseph's brother Arthur married Louisa Kenrick who was Florence's twin sister; and William Kenrick, Harriet's brother, married Mary Chamberlain, Joseph's sister. Thomas Martineau married Emily Kenrick, elder sister of the twins Florence and Louisa ${ }^{19}$. Beyond familial connections, a wealth of commonalities bound this group, including shared business interests in industry and banking, shared Unitarian beliefs and other social links ${ }^{20}$. All were

\footnotetext{
${ }^{16}$ Chamberlain's family followed Joseph Chamberlain to Birmingham from their native London following their profitable investment in the screw-making business, and became entrepreneurial investors in numerous industrial projects there.

${ }^{17}$ The Kenrick family enterprise and fortune centred on a metal hardware-manufacturing firm in West Bromwich founded by Archibald Kenrick in the eighteenth century. In 2015, the firm is still manufacturing, specialising in locks and security devices. (RA Church, Kenricks in Hardware: A Family Business 1791-1966, (David and Charles, 1969)).

${ }^{18}$ The Martineau family were active in the legal and medical professions as well as in industry, and provided five generations of mayor for Birmingham between 1846 and 1973. Since 1851, Thomas Martineau's legal partnership (with Arthur Ryland, his mother's first cousin) in Birmingham, has grown to become, today, the firm of SGH Martineau, a major global international law firm.

${ }^{19}$ Alice Kenrick (1845-1940), another sister of Emily, married solicitor Charles Gabriel Beale (1843-1912), thrice Lord Mayor of Birmingham, 1897-1900.

${ }^{20}$ As early as 1855 , Joseph Chamberlain, William Kenrick and Thomas Martineau are recorded together as members of the Edgbaston Debating Society (Louis Creswicke, The Life of Joseph Chamberlain, (Caxton,
} 
Liberals and, when required, followed Chamberlain to join the Liberal Unionists after the break with the Gladstonian Liberals. The neutral statistical approach used below will confirm the strength of the ties on the town council evident between these individuals. Some might feel it fair to require that a test of any analysis of the support available for Joseph Chamberlain on the Birmingham town council must invoke these names: if these names at least, along with that of Joseph's close friend Jesse Collings, failed to appear, then the analysis must be flawed.

On the other side, and less easy to determine, Chamberlain faced Birmingham town council members who can be counted as Chamberlain's political opponents. At the outset, John Sadler and William Brinsley can be named as leaders of the main group opposing Chamberlain's expansive ideas and policies. The centrality of Sadler and Brinsley to this opposition is clear and was well-known at the time ${ }^{21}$. The Chamberlain-aligned Birmingham Daily Post noted "when Mr Allday died the leaders of [his] party ... became Mssrs. Sadler and Brinsley"22 and on Sadler's retirement the newspaper begrudgingly praised 'the ability with which he formerly conducted the affairs of the party which acted under his guidance...,23. John Sadler was to become mayor in 1871 and, strikingly, his mayoral election victory over Arthur Ryland was the sole contested mayoral election on council between 1865 and 1880. The antagonism between Sadler and Chamberlain and his supporters is shown by a bitter public correspondence which arose when Chamberlain became a candidate for mayor in October $1873^{24}$. Sadler accused Chamberlain of "stupidity", “deception" and "political inaccuracy and recklessness of speech". Chamberlain's allies

1904) p33). The Chamberlains, Kenricks, Martineaus, Arthur Ryland and Jesse Collings were all members of the non-conformist Unitarian sect at the Church of the Messiah on Broad Street (where the Reverend Crosskey preached the civic gospel). The inaugural meeting of the Birmingham Educational League in 1869 included Joseph Chamberlain, Jesse Collings, William Kenrick (and his father Timothy Kenrick) and Arthur Ryland. Among the first directors of the Lloyds Banking Company Ltd were Joseph Chamberlain, Arthur Ryland, Timothy Kenrick and JA Kenrick: Thomas Martineau was the bank's solicitor.

${ }^{21}$ BDP 10 Oct 1872

${ }^{22}$ BDP 14 Aug 1906

${ }^{23}$ BDP 10 Nov 1877

${ }^{24}$ BDP 1 Oct and 2 Oct 1873 
responded that Sadler used "scurrilous abuse" and "duplicity" and had been "long in the habit of trusting to his imagination for his facts". William Brinsley, although humbly describing himself as a "grocer", was a large-scale wholesale trader, general investor and rentier, admitting $^{25}$ annual trading returns of $£ 12-£ 14,000$ : he became wealthy enough to bequeath $£ 20,000$ to Birmingham charities. He was councillor, alderman and on the Watch Committee for lengthy periods from $1855^{26}$ : "Mr Brinsley attached himself to a party which made rigid economy its first consideration [which] brought him into sharp conflict with the progressive band of reformers whom Mr Chamberlain rallied to his side."27

From reports of members and attenders of Allday's Ratepayer Protection Society meetings, and from information on those consistently supporting Allday on council in earlier times, the identities of some of the "economist" group may be inferred and some of these were still members of council after November 1865 when the period of our study begins, including: Thomas Aston, John W Cutler, John Gameson and George Goodrick. Finding any of these names appearing in a network of Chamberlain's supporters would be highly surprising: finding John Sadler and William Brinsley among them would damnify the research. That the loosely-applied Liberal and Conservative labels cannot be relied upon to identify Chamberlain's friends and foes is now easy to demonstrate. John Sadler himself remained a member of the Birmingham Liberal Association until his death. Thomas Aston, one of Allday's economists, was a Liberal Association member, although in 1873 his electoral support was noted as coming from Conservatives (and "publicans and Catholics") and his election was contested by a fellow Liberal ${ }^{28}$. William Rolason, also a member of the Liberal Association, but "vigorously supported by the Tories" 29 stood unsuccessfully against a fellow

\footnotetext{
${ }^{25}$ BDP 24 October 1879

${ }^{26}$ Briefly interrupted by a hiatus following a scandal concerning over-lenient treatment by the police of one of his shadier friends.

${ }^{27}$ London Times, 15 August 1906.

${ }^{28}$ BDP 3 Nov 1873

${ }^{29}$ BDP 3 Nov 1874
} 
Liberal in 1874. Numerous other members of the Birmingham Liberal Association, it will be shown below, did not support the Chamberlain group's positions on council, including John Carter, Edward C. Osborne, Thomas Prime and Michael Maher (Jnr).

The Conservative label similarly proves an unreliable indicator of allegiance. The tactical struggle over the policy to be pursued with regard to sewage treatment in 1871 was a pivotal moment as the first important battle won in the takeover of the council by Chamberlain's reforming group. In the long-drawn-out sewage policy debates ${ }^{30}$ which stretched over the summer months of 1871, Chamberlain found able allies in two long-serving council members, Thomas Avery and Henry Hawkes, who, with Chamberlain, spearheaded the decisive debates that wrested control of sewage policy away from the Public Works Committee on council. But Thomas Avery was a steadfast Conservative, albeit never an economist, who "invariably supported ... Liberal policy on council" believing "wealth can always take care of itself, but poverty cannot..." Joseph Chamberlain's achievements in Birmingham on the latter's resignation from council $^{32}$. Henry Hawkes ${ }^{33}$ was a Radical, a veteran of the turbulent Birmingham political scene of the 1830 s and 1840 s and had been, for a spell, President of the Birmingham Liberal Association, but after thirty years on the council, Hawkes resigned to become Town Coroner in 1875 and eventually stood, unsuccessfully, as Conservative candidate for Parliament.

There were, therefore, on Birmingham's town council, those labelled Liberals opposed to Chamberlain's new approach and those labelled Conservatives supporting it. There were, moreover, over 130 men who were individually members of the Birmingham town council over the period of Chamberlain's tenure, and for only a few does enough documented

\footnotetext{
${ }^{30}$ See Bunce, pp126-139; and Leslie Rosenthal, The River Pollution Dilemma in Victorian England (2014, Ashgate), pp57-90

${ }^{31}$ BDP 19 Feb 1894

${ }^{32}$ BDP 26 May 1880

${ }^{33}$ BDP 28 Sept 1891
} 
biographical detail alone survive to give plausible answers to queries about whether or not they were members of Chamberlain's band of backers.

Crucial biographical information being elusive, the core of this paper analyses the voting behaviour of members of the Birmingham town council to identify Chamberlain's most loyal supporters and his bitterest opponents. Brief biographical information is presented for all highlighted councillors in the Appendix.

\section{Method and Data}

The minutes of the Birmingham town council assiduously record "For" and "Against" voting lists that allow this exploration of voting networks on the town council. Town council sessions lasted November-to-October for each year, and the data analysed here was collected from sixteen annual town council sessions from $1865 / 6$ to $1880 / 1$, inclusive ${ }^{34}$. All sixty-four councillors and aldermen could vote and a total of 152 different individual members of the council on the voting lists were recorded over the sixteen-year period ${ }^{35}$. For each member, a record was constructed showing whether the member voted and, if so, registered the binary choice ("For" or "Against") made on the motion (or on a choice of candidacy for a committee or mayoral vacancy). Over the entire period there were 272 roll-calls used; the largest number of roll-calls within a single annual session was thirty-six and the fewest was five.

The dataset as explored here ${ }^{36}$ uses the approach of social network analysis, viewing social networks as a series of "nodes" (objects, people) interconnected by "vertices" (links or ties or

\footnotetext{
${ }^{34}$ Birmingham Town Council Minutes, Birmingham City Archives, Birmingham Central Library, BCC.

${ }^{35}$ All proposals are treated with equal weight no matter how seemingly trivial. The database is restricted to rollcalls with at least forty members of council present and where the minority vote numbered at least five. Only the final roll-call on any individual motion, after any amendment, is included in the database.

${ }^{36}$ The sizeable annual turnover of councillors and other factors leave much missing data in the database, which precludes the application of forms of cluster analysis seen in other studies of parliamentary processes : see L. Kaufman and P. Rousseeuw, Finding Groups in Data: An Introduction to Cluster Analysis, (1990, John Wiley \& Sons; John Hoadley, 'The Emergence of Political Parties in Congress, 1789-1803', American Political Science Review, vol 74, no 3, Sept 1980; Royce Carrol and Keith Poole, 'Roll Call Analysis in the Study of Legislatures', in Shane Martin, Thomas Saalfeld and Kaare Strøme (eds) the Oxford Handbook ofLegislative Studies, (2014, OUP).
} 
edges) ${ }^{37}$. For the Birmingham town council, individual council members are the nodes in the network and the links between nodes carry measures of the strength of the voting relationship between the members. This relationship between each pair of council members is measured by the "degree of voting agreement" revealed by the mutual voting behaviour of the two members in the pair. If both Person A and Person B vote on a particular issue (Proposal X), and they vote the same way - either both "For" or both "Against" - then they are in agreement: if both in the pair vote and vote in opposing lobbies, then they in disagreement: if either Person A or Person B is absent, or not at that time on council, or does not vote, neither agreement nor disagreement is recorded and the data becomes "missing". The "degree of voting agreement" showing the strength of the link between Person A and Person B is the straightforward metric: "proportion (percentage) of times when both voted, that they voted in agreement". The visualisation tools of social network analysis used here provide straightforward and easily understandable graphical representations, and figures showing the resultant networks of nodes and vertices and the interlocked networks can then be searched for evidence of groupings with particularly high commonality of voting behaviour. This commonality will be taken to indicate "systematic" voting, revealing sub-groups and networks within the council.

The degree of voting agreement for any pair of members may be calculated over any arbitrarily chosen time period required: possibly for single year sessions or, alternatively, for the data pooled over a number of annual sessions. If annual council sessions are taken separately, then some of the sixteen years have too few council voting roll-calls to produce convincing evidence, but at the other extreme, pooling the data for the entire sixteen years into a single whole fails to show networks developing over time and may miss fine detail and short-lived allegiances.

\footnotetext{
${ }^{37}$ Derek Hansen, Ben Shneiderman, Marc A. Smith, Analyzing Social Media Networks with NodeXL: Insights from a Connected World (Morgan Kaufmann, 2010).
} 
The results presented below are restricted to just four periods of time, each period pooling the data from four annual sessions of council business. This is a pooling of the data over the sixteen years which provides a reasonable series of pictures of the council's progress, gives adequate numbers of roll-calls, and avoids any problems of assimilating large quantities of results $^{38}$. The four four-year periods are:

(a) November 1865 to October 1869: the four years before Joseph Chamberlain first entered council (in November 1869) to show the situation on council pre-Chamberlain; (b) November 1869 to October 1873: the four-year period of the rise of Chamberlain on the town council, between his entry to the council up to his first session as mayor; (c) November 1873 to October 1877: covering Chamberlain's mayoralty, beginning in November 1873; and,

(d) November 1877 to October 1881: the period after Chamberlain's mayoralty (including following his resignation in May 1880).

With sixty-four council members, even a single council session year would produce 2016 possible one-to-one pairings or links ${ }^{39}$. For pairs of council members mutually on council, all links will, of course, have some degree of agreement ${ }^{40}$ which can range from zero per cent (where the pair always vote differently when both vote) to one-hundred per cent (where the pair always vote identically when both vote). So to be convincing that, rather than mere chance, some linkages and voting agreements may be due to some more fundamental "agreement of view", the degree of voting agreement must, crucially, be measured over a sufficiently number of voting occurrences, and must be high enough, to exclude the possibility of being due to mere common chance. To these ends, two criteria are utilised:

\footnotetext{
${ }^{38}$ Other organisations of the data over time periods were (quite labouriously) examined, and no substantial and/or defensible revisions to the general conclusions below are to be derived from other re-divisions of the data over time periods.

${ }^{39}$ For a fully connected network of $\mathrm{N}$ nodes the number of links will be $\mathrm{L}=(1 / 2) \mathrm{N}(\mathrm{N}-1)$.

${ }^{40}$ Ignoring missing data or formal problems of division by zero.
} 
(i) the pair in the link must have both voted on the same motions at least twenty-five times over the four-year period concerned; and

(ii) links must display at least an $0.85(85 \%)$ degree of agreement ${ }^{41}$.

Only one-to-one pairings (links) satisfying both criteria are retained. If it were that voting behaviour was purely independent and unconnected between the voters, observing a link satisfying both criteria would occur very rarely, expected only once or twice in every 1000 links ${ }^{42}$. In fact, there emerge large numbers of such occurrences in the data, many more, given the number of one-to-one pairs, than would be reasonable had the individuals been voting independently. The implication is, therefore, that when links survive the application of the two criteria, some coordination or commonality of interest exists between the two individuals in the linked pair.

\section{Results}

The results are presented separately for each of the four four-year council session periods. Beyond applying the stated criteria to the council voting data, no other biographical information is used to produce these results.

\section{a) November 1865 to October 1869: "Before Chamberlain"}

The pooled data from the first four-year period, $1865 / 6$ to $1868 / 9$, contains only a bare scattering of voting links between members that pass the two critical criteria.

\footnotetext{
${ }^{41}$ For the links passing both criteria, the actual mean number of shared voting occasions and the actual mean degree of mutual agreement will be higher than these minimum cut-off levels.

42 This is a consequence derivable from probability theory. A pair of individuals making independent binary decisions purely randomly, say by tossing fair coins, would be expected to make identical decisions (both $\mathrm{F}$ (For) or both A (Against)) in one-half of the occasions where they both vote, and the degree of agreement arising by chance between the two would be expected to settle down at $0.5(50 \%)$ over a series of such votes/tosses. The greater the number of votes/tosses in the experiment, the closer to this expected value would the actual outcome be expected to settle. For the two criteria above to hold, of the 25 mutual votes required, 21 or more $(85 \%)$ would have to be FF or AA rather than FA or AF. The Binomial Theorem tells us this is expected to occur by chance for a pair of voters acting independently (and each voter voting $51 \%$ of the time for F) only around once in every 10,000 such trials, and we would see only one or two such occurrences in the results below. (The $51 \%$ arises because, in this data, unlike heads or tails in fair coin tossing, F votes were recorded about $51 \%$ of the time (over the 16 years, of votes cast, 6,459 were $\mathrm{F}(51.4 \%$ ) and 6,104 were $\mathrm{A}$ $(48.6 \%)))$.
} 


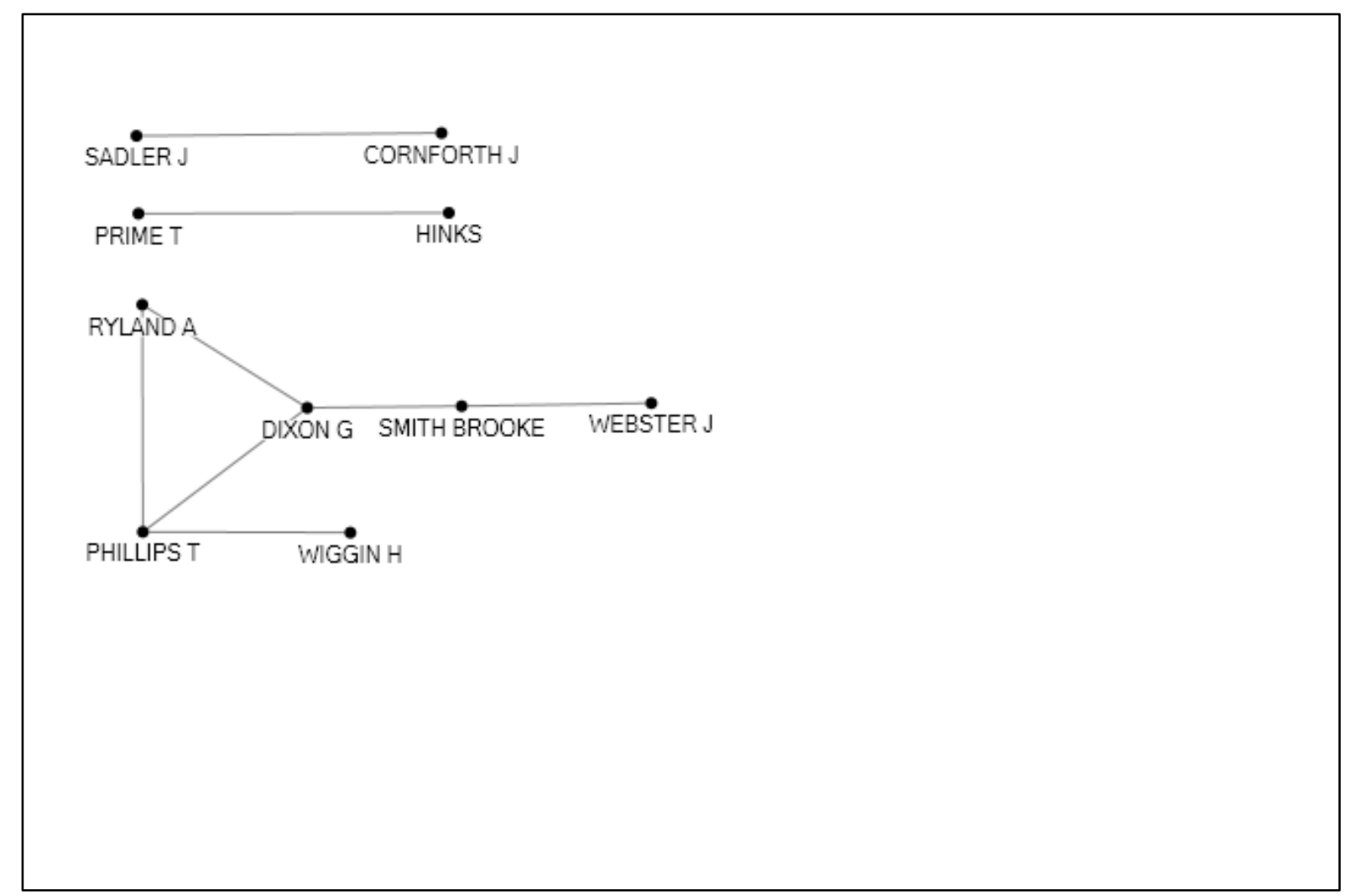

Figure 1 Voting Links: 1865/66-1868/69

The few links that survive are shown on Figure 1 indicating, to emphasise, that, for example, Ryland voted on at least $85 \%$ of at least 25 occasions with Phillips and Phillips voted on at least $85 \%$ of at least 25 occasions with Wiggin: but that one or other or both of the two criteria did not hold between Ryland and Wiggin. In truth, the configurations of Figure 1 barely deserve to be called "networks", but, however, this bare-bones result usefully serves to emphasise the substantial changes that will be observed for later periods once Chamberlain joins the council.

However, even among the surviving ten named individuals and three groupings shown (of a total of eighty-one members present on council over this period) the figure includes many prominent among Birmingham's political elite of the time. The largest grouping on Figure 1, containing six members, George Dixon, Arthur Ryland, Henry Wiggin, John Webster, Brooke Smith, and Thomas Phillips, form a distinguished assembly, including four mayors of 
Birmingham and two future MPs. Beyond their voting patterns, all six display biographic details which would place them within the circle around Chamberlain, with common nonconformism and commercial banking interests ${ }^{43}$ featuring strongly ${ }^{44}$. Central to this group is George Dixon ${ }^{45}$, sometimes called "the third man of Birmingham" (eclipsed only by Joseph Chamberlain and John Bright); his short stay on the town council included his mayoralty for 1866/7 and ended when he took the deceased William Scholefield's Birmingham constituency Parliamentary seat in 1867. Dixon shared with Chamberlain the founding and leadership of both the Birmingham Education Society and the National Education League. Arthur Ryland, "prince among solicitors", had first been on the town council in 1854, becoming mayor in 1860/61. He had multiple social links with Joseph Chamberlain, was legal partners with Chamberlain's brother-in-law, Thomas Martineau, and they shared Unitarianist beliefs. (Sir) Henry Wiggin, major industrialist and metal manufacturer, knighted in 1892, had been a council member from 1861, including being mayor in 1864/5: from 1880-92, he was first a local Liberal MP and then followed Chamberlain as a Liberal Unionist MP. Thomas Phillips, a wine merchant and director of the early Midland bank, had been mayor in 1844 and was also a Unitarian. The remaining two members of this six-man grouping, John Webster and Brooke Smith, were both long-established council members, both founder members of the Birmingham Liberal Association in 1865 and had welldocumented social and commercial ties with Chamberlain's circle.

The remaining four named members in the other two detached pairs of Figure 1 have voting records much more closely aligned with each other than with the six-man group discussed

\footnotetext{
${ }^{43}$ Birmingham saw the founding of both the Midland Bank and Lloyds Bank, two of the giant "Big Five" banks that dominated British commercial banking for a century. Dixon, Joseph Chamberlain, Kenrick, Ryland and Brooke Smith were directors in the early Lloyds Banking Company. Webster, Phillips and Ryland were directors of the nascent Birmingham and Midland Bank.

${ }^{44}$ Brooke Smith, Phillips and Webster will reappear in later periods. After 1869, Dixon left the council for Parliament and Ryland and Wiggin became too irregular as attenders to meet one of our criteria. 45. James Dixon, Out of Birmingham: George Dixon (1820-1898): Father of Free Education, (Brewin Books, 2013).
} 
above. None were friends of Chamberlain's group. Sadler has already been noted as one of Joseph Chamberlain's consistent opponents, and John Cornforth was described as a supporter of Sadler's party and one who "did not take cordially to the new regime which is associated with Mr Chamberlain's connection with the council."46 The final link on Figure 1 connects Thomas Prime with John Hinks. Prime, mayor for 1869/70, was a long-term Liberal council member but also an Allday-connected economist. Hinks was also a "staunch Liberal"^7, but one who also believed council expenditure must be kept down and that "... he should act always on a principle of strict economy ${ }^{\text {,48 }}$. The pair remained equally closely aligned in their voting patterns in the next period, but still intriguingly unconnected, on our criteria, with either of the groups around Chamberlain or Sadler.

As noted, only ten council members appear in Figure 1 for this period immediately before Chamberlain's entry ${ }^{49}$. Compared to what we will see for the next periods, the voting networks derived for 1865/6-1868/9 are sparse and basic and it would be premature to conclude much about any general "partisanship" that might exist on the Birmingham town council at this time. Nevertheless the few voting connections that do arise from the network analysis are clearly by no means out of line with inferences from available biographical information.

There was a substantial turnover of members on the Birmingham town council between the four year period 1865/6-1868/9, and the next period, 1869/70-1873/74. A new influx of councilmen provided new names and voting patterns and included Joseph Chamberlain as councillor for St Paul's ward from November 1869.

\section{b) November 1869 to October 1873: "Chamberlain's Rise"}

\footnotetext{
${ }^{46}$ BDP 11 Apr 1888.

${ }^{47}$ BDP 14 Feb 1885.

${ }^{48}$ BDP 11 Nov 1865.

${ }^{49}$ Missing from the figure are some prominent council members including Thomas Aston, Ambrose Biggs, William Brinsley, Jesse Collings and George Braithwaite Lloyd.
} 
The second four-year period of 1869/70-1872/3 shows a much more extensive and complex pattern of voting allegiances on the Birmingham town council. As shown in Figure 2, the analysis collects a large number of members into three voting groups.

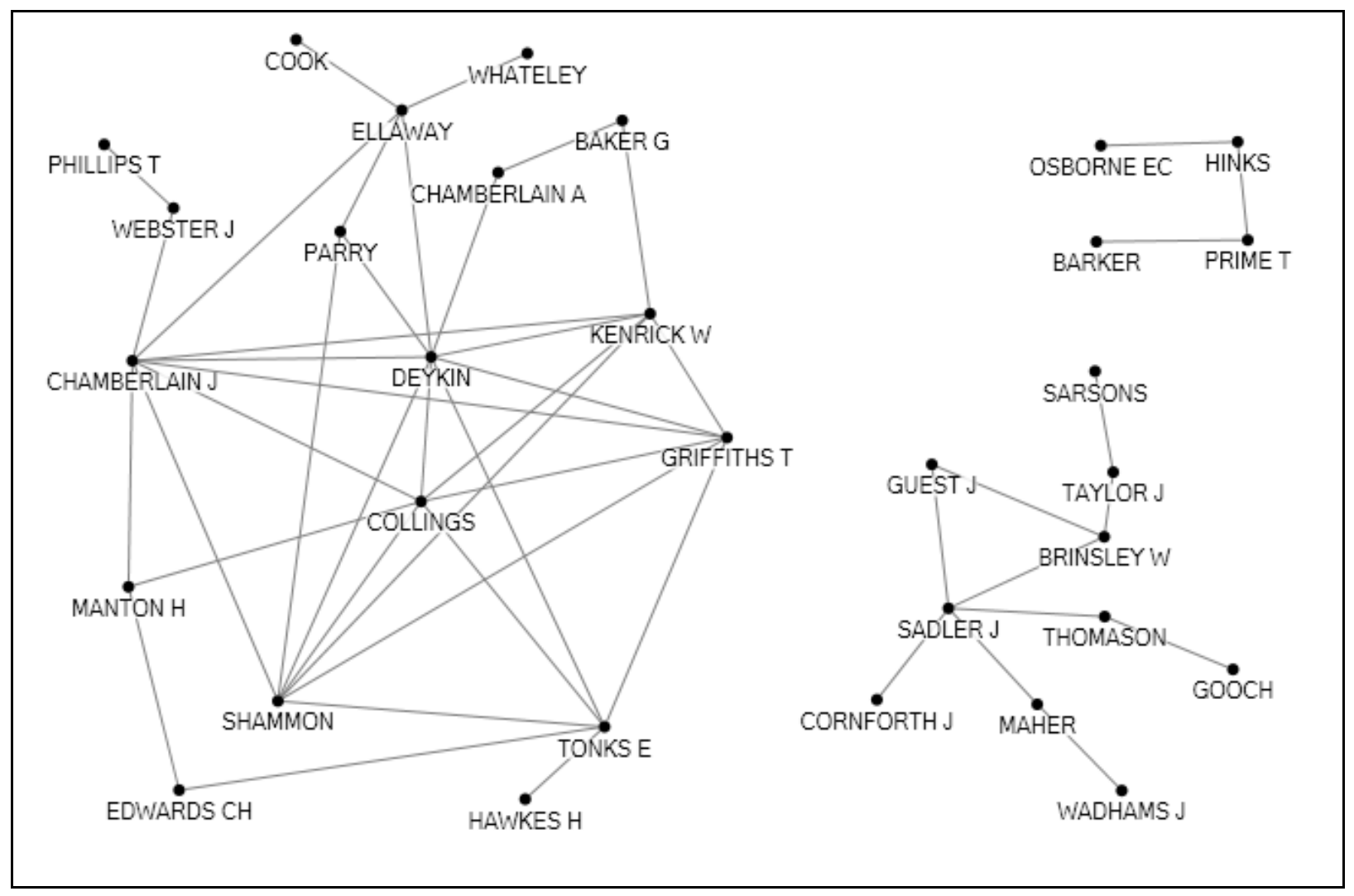

Figure 2 Voting Links: 1869/70-1872/73

The largest is a seventeen-strong group including Joseph Chamberlain and many of his known supporters. A second large grouping of ten members is centred on John Sadler and William Brinsley and includes, as will be demonstrated, a number of council members identifiable as opponents of Joseph Chamberlain on the council. John Sadler himself was elected mayor in the middle of this period, in November 1871, so his influence cannot be doubted. A third group of four-members, not aligned to either of the other groups, also exists. These groupings as a whole contain thirty-one of the total of eighty-seven named members of council who served over this period. There has emerged, it is clear, a partisan structure within the council. 
The large seventeen-man Joseph Chamberlain-connected group constitutes a complexlooking network, with many interlinked voting associations between its members. There are now some "usual suspects" among the councillors, including Joseph Chamberlain's newlyelected brother Arthur Chamberlain, Jesse Collings ${ }^{50}$ and William Kenrick, all of whom, to be blunt, it would be surprising not to see in the grouping with Joseph Chamberlain. Thomas Phillips and John Webster, noted as likely Chamberlain supporters for the first period, also re-appear here. A number of the other members appearing alongside Chamberlain in this network in Figure 2 played notable roles in Birmingham's civic history. George Baker, “one of Chamberlain's band of men",51, was Chamberlain's replacement as mayor in 1876 and will reappear in future Chamberlainite groupings alongside his brother and fellow councillor, John Edward Baker. Henry Manton had been mayor in 1861 and remained a council member for over fifty years from 1852 until his death, still in office as "Father of the council" in 1903. Henry Horne Ellaway came on the council in 1870 and he too will re-appear in a later period, before retiring in 1883 and dying, aged only 54, in 1887.

But within this large group there are also names undeservedly absent in histories of Birmingham at this time. Indeed, if the importance and centrality of an individual in the network is judged by the number of connections or links involving that node/individual (its "degree"), then the group's most central member is not Joseph Chamberlain but James Deykin, who remains equally well-connected to the groups voting with the Chamberlain faction in both the following periods too. James Deykin was a key element driving and supporting the Chamberlain policies on the Birmingham improvement scheme and the municipalisation of the water company, but he died early, accidentally drowned in Aston Reservoir, and remains little known. William Shammon is another member very wellconnected within the Chamberlainite group in this period and the next. Shammon was said to

\footnotetext{
${ }^{50}$ Jesse Collings and John L Green, Life of the Right Hon. Jesse Collings, (1920, Longmans).

${ }^{51}$ Society of Friends, Annual Monitor, 1911.
} 
have "lent all the support he could to the municipal and Parliamentary work of $\mathrm{Mr}$ Chamberlain" ${ }^{52}$ : he followed Chamberlain from the Liberals to the Liberal Unionist cause, and was rewarded by Chamberlain calling him a "most loyal friend and fellow-worker"53. Two more, Thomas Griffiths and Edmund Tonks were active on council and are also wellconnected in this network, but they remained on the town council for only relatively brief periods. The prickly ex-Radical Henry Hawkes also appears in the network, and this large 17man group around Chamberlain is completed by the less prominent councillors Charles Henry Edwards, Peter Parry, and the former Chartist James Whateley, each of whom appear once only in these voting network figures.

As well as the network containing Joseph Chamberlain, Figure 2 also shows a sizable tenman voting network of "old guard", economist-Liberal and Conservative council members around John Sadler and William Brinsley. This group were certainly no friends of Joseph Chamberlain or his policies: We can highlight the differences in voting patterns between this ten-man economist-Liberal group and the seventeen-man Chamberlain-Liberal group. Within Chamberlain's seventeen-man group the average degree of agreement for voting identically with Joseph Chamberlain himself, is 85.2\%: within the ten-man Sadler-Brinsley-connected group the average degree of agreement for voting as Chamberlain did is $24.7 \%$. Taking John Sadler as the centre of this ten-man group, the average degree of agreement between Sadler and the rest of his group is $86.3 \%$ : for the members of the Chamberlainite group, the average degree of agreement with Sadler's voting record is $26.8 \%$.

For the members of this ten-man Sadler-Brinsley group, strong biographic evidence may be found for lack of sympathy with Chamberlain's cause at this time, especially its nonconformist and temperance attitudes. Sadler, Brinsley, and Cornforth have already been

\footnotetext{
${ }^{52}$ BDP 5 Jan 1894

${ }^{53}$ BDP 10 Jan 1894
} 
labelled as associated with the economists of Joseph Allday's "Woodsmen", and Sadler and Cornforth form one of the pairs on Figure 1 for the first period, 1865-1869. The remaining seven comprise a collection of greater or lesser prominence on the town council, but include some other men of stature in the town. James Guest, who was a councillor from 1860 until 1871, was an important figure for Birmingham. He had earlier played a major role in the liberal and Radical agitation for an end to the tax and duty on newspapers and similar publications, and had spent a principled spell in gaol for the cause: now he was protective of the shop-keeper interest and retained a belief in low local taxes generally, declaring he would: "...always vote for the least expenditure compatible with the exigencies of the borough... ${ }^{, 54}$. Joseph Taylor and Henry Sarsons, both commonly viewed as Conservatives, ${ }^{55}$ were both members for Duddeston-cum-Nechells and "a familiar association to the ward" Michael Maher (Jnr) who had "the support of Mr Brinsley, the publicans, and the Catholics and Irish of the town"57 and Joseph Wadhams, said to have "never voted on the extravagant side ${ }^{, 58}$, were prominent in support of the alcohol-based trades, for which the town council's licensing role was important. The group is completed by Ephraim Gooch and John Thomason, a "consistent advocate of economy"59. Maher, Gooch and Thomason, like Sadler, were Liberal Association members. This ten-man group around Sadler and Brinsley forms, it is clear, the core of what may be considered an economist and anti-Chamberlainite group on the council at this time.

Figure 2 also shows a final group of four members, Hinks, Prime, Osborne, and Barker, who form a further, separate, network of voters. On average, this group votes in agreement with Chamberlain on $54.9 \%$ of occasions and with Sadler $61.9 \%$ of the time: among themselves

\footnotetext{
${ }^{54}$ BDP 25 Oct 1865

${ }^{55}$ Taylor: "They call me a Conservative ... I am proud to be called one" (BDP 1 Nov 1882). Taylor and Sarsons were both supported by the (Conservative) Duddeston Labour Representation League.

${ }^{56}$ BDP 14 Feb 1887

${ }^{57}$ BDP 13 Nov 1873

${ }^{58}$ BDP 3 Apr 1871

${ }^{59}$ BDP 13 Apr 1892
} 
the average is $83.8 \%$. This four-man intermediate group can be classified as neither Chamberlain's friends nor his enemies. Hinks and Prime have already featured in Figure 1 and form one of the (politically intermediate) pairs there, and the other two were also wellestablished council members. Edward Corn Osborne was a member for thirty years, until 1882, and had been offered, but refused, the mayoralty: he played an important compromise role in the council's defining sewage debate wars of the early 1870s. Stephen Barker also served on council for nearly twenty years, and though a successful and wealthy industrialist, he played only a moderate role on council.

The voting analysis conducted for this period of Chamberlain's rise on council shows the membership of Birmingham's town council forming divisions which can be seen as, in turn, backing, opposing and unaligned to Chamberlain. The next period will show an even more dominant position held by Chamberlain's group.

\section{c) November 1873 to October 1877: "Chamberlain's Mayoralty”}

The third four-year period, $1873 / 4$ to $1876 / 7$, includes the critical time of Chamberlain's spell as mayor of Birmingham from November 1873 until June 1876, when he resigned the mayoralty to take up Dixon's Birmingham Parliamentary seat. Figure 3 graphs the pattern of voting networks derived. There is a large and expanded (twenty-two-man) group of members with links and connections involving Joseph Chamberlain and friends, and a quite depleted, now only five-man, group of members associated with Sadler and Brinsley. Two further separate minimal pairings satisfy the voting criteria and these have voting preferences that are much closer to the Sadler-Brinsley group than to Chamberlain's, but not enough to form an allowable $\operatorname{link}^{60}$. The partisan structure within the council has certainly persisted, with a

\footnotetext{
${ }^{60}$ There were a total of eighty-five named individuals who spent time on council over this four-year period, many of whom only marginally fail to fulfil the criteria set to become linked to vertices within the figure.
} 
fracturing, perhaps, of the opposition's cohesion, and an increase in the relative dominance of Chamberlain's group.

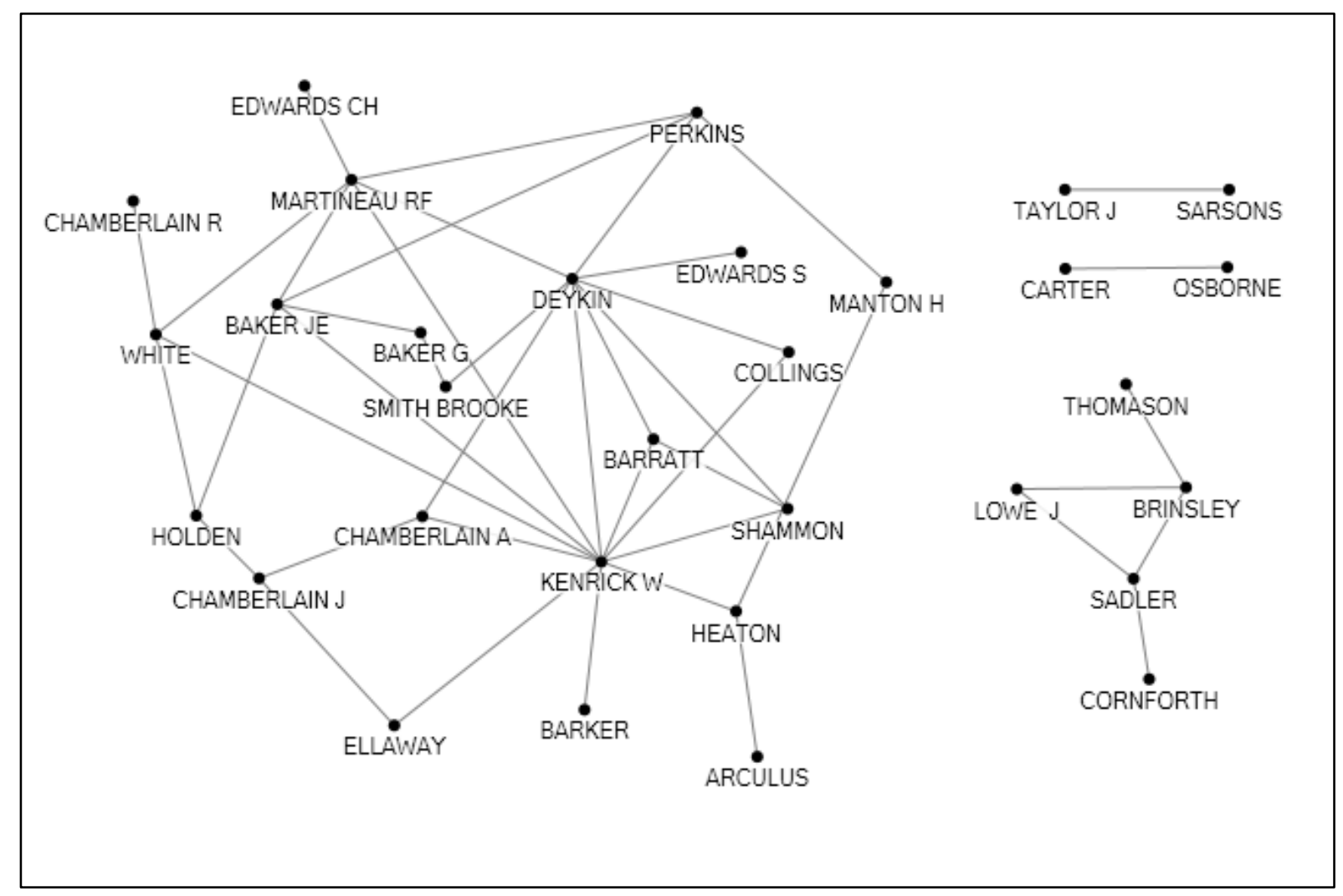

Figure 3 Voting Links: 1873/74-1876/77

Among the network with Joseph Chamberlain, there are eleven who were present as members of the Chamberlain reform group for the previous four-year period. Ten names are new and one (Stephen Barker) was part of the intermediate group in Figure 2 above ${ }^{61}$. Again, central roles within this network are played by William Kenrick, George Baker, William Shammon and James Deykin ${ }^{62}$. Included in the new names are some from the Chamberlain family circle, who became influential on council, and will reappear in the networks below. Chamberlain's brother Richard Chamberlain joined the council in 1874, and he was to stay for twelve years until 1886, including as mayor for 1879-80 and 1880-81, before becoming a

\footnotetext{
${ }^{61}$ Of the six in the Chamberlain group in Figure 2 who are missing from Figure 3, Phillips died and Hawkes, Griffiths, Parry and Webster retired from council. Whateley narrowly missed any $85 \%$ link criterion.

${ }^{62}$ The relatively peripheral position of Joseph Chamberlain and Jesse Collins in the network may be due to their extended leaves of absence from council following the death of Florence Chamberlain,
} 
Liberal, then Liberal Unionist, MP. Robert Francis Martineau was elected to council in 1874, to remain as councillor and alderman until 1909, arriving on council two years ahead of his younger brother, (Sir) Thomas Martineau.

Other new members appearing here will reappear below in Chamberlain-connected networks. William White, the Quaker philanthropist, who was first elected in 1873, became an influential figure, becoming mayor for 1882/3, and is often cited as a major mover in the Birmingham Improvement scheme. Also destined to re-appear are John Edward Baker, who became a councillor in 1872, brother to fellow Quaker George Baker, and William Perkins who was to spend a total of seventeen years on council (though without significant impact).

New arrivals who played active roles on council were Dr Alfred Barratt, central to proChamberlainite sanitary and health policies, and Samuel Edwards who would become Lord Mayor for 1900/1. Ralph Heaton, also a long-serving council member, was, notably, a council member among the voting networks of Chamberlain's allies described by the local media as a "staunch Conservative"63. The remaining two newly-appearing names in the network served only short periods: Alfred Arculus died suddenly in 1875 and Arthur Holden served only a single session, from 1874 .

While the group around Chamberlain has retained membership size and cohesion compared to the earlier period, the opposition Sadler-Brinsley group has dwindled. Cornforth ${ }^{64}$ and Thomason remain as part of this five-strong group alongside Sadler and Brinsley, as they were during the previous period, and the group is completed by John Lowe, a "Tory stalwart"65 and mainstay of the Conservatives in Birmingham in the late 1870s. The remaining two separate linked pairs of individual members on Figure 3, Carter and Osborne,

\footnotetext{
${ }^{63}$ BDP 20 Nov 1891

${ }^{64}$ Cornforth and Brinsley share the distinction of earning a $100 \%$ degree of agreement over this period.

${ }^{65}$ Stephen Roberts and Roger Ward, Mocking Men of Power: Comic Art in Birmingham 1861-1911 (2014, CreateSpace Independent Publishing), p 44.
} 
and Sarsons and Taylor, although failing the criteria necessary to link up with the SadlerBrinsley group, display voting agreements much closer to the Sadler-Brinsley group than to Chamberlain's. Of these four, the pairing of Sarsons and Taylor has appeared earlier. For the final pair, Alderman Osborne has also already appeared but John Carter was another veteran Liberal-economist of the old school, whose councillorship reached back to the Allday era, and who retired from council in 1878 , "out of harmony with changed conditions" 66 .

The dominance of Chamberlain's dependable party grouping has been seen to have persisted into and through Chamberlain's period as mayor of Birmingham. For the fourth period, we will see the continuation of this process and the total disappearance of any opposition group.

d) November 1877 to October 1881: "After Chamberlain”

The final four-year period takes us slightly beyond the time of Joseph Chamberlain's presence on Birmingham council ${ }^{67}$, and serves to underline the continuing dominance and influence of those with whom he was closely associated. For this period, as shown on Figure 4, the network analysis has discovered only a single network of voting concordances that satisfy the criteria set.

\footnotetext{
${ }^{66}$ BDP 16 Feb 1905

${ }^{67}$ Joseph Chamberlain remained an alderman until retiring formally in May 1880, having not voted for about a year and failing the voting criterion for this period.
} 


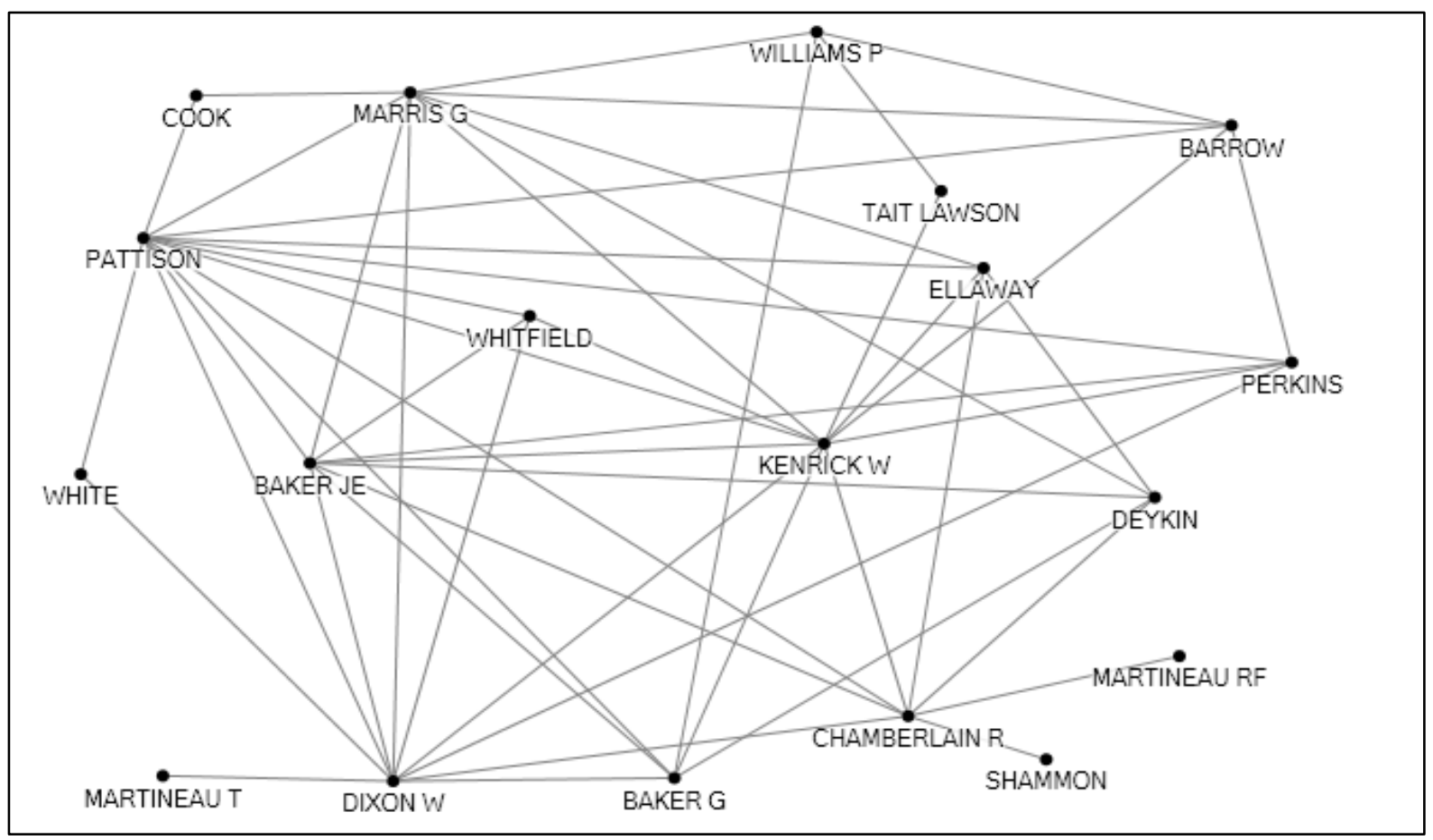

Figure 4 Voting Links: 1878/79-1880/81

The single nineteen-man group remaining is composed entirely of allies of Joseph

Chamberlain and supporters of his policies. Ten of the names within this group have already been identified as associates of Joseph Chamberlain and appear in earlier networks with him, including Richard Chamberlain, William Kenrick, James Deykin, George and John Edward Baker and Robert Francis Martineau. Of the newly-appearing names, four are of particular interest. Joseph Powell Williams was a close confidant of Joseph Chamberlain and played a notable political role both locally and nationally. In Birmingham, Powell Williams orchestrated the finding of funds for the town's urban renewal and, as MP for South Birmingham for eighteen years after 1885, supported and backed Chamberlain in Parliament. (Sir) William Cook, was mayor in 1882 and was briefly Liberal MP for Birmingham East (1885-86) and is viewed as central in pushing through the scheme to clear and redevelop the slums of central Birmingham. (Sir) Thomas Martineau who married into the ChamberlainKenrick-Martineau family social network, was to be thrice mayor of Birmingham (the second 
of five Martineau mayors of Birmingham, so far): he joined the council in 1876 to sit alongside his brother Robert Francis Martineau. Of equal interest is Richard Cadbury Barrow who entered the council in 1871 and rose to become mayor in $1888 / 9$, an "... ardent supporter of the reforms [of] Mr Chamberlain"68. Barrow's presence here allows an explicit political connection to be made between Chamberlain's reformers and the Cadbury-Barrow family, another of the great non-conformist (here Quaker) industrial clans of Birmingham. Richard Cadbury Barrow had taken on the retail side of (his uncle) John Cadbury's tea and cocoa business whilst John's sons, Richard Cadbury (1835-1899) and George Cadbury (1839-1922) took on the chocolate production side, soon steering the Cadbury Bros Ltd chocolate company to global celebrity. Barrow was only the first of a number of this family who joined the town council up to the 1990s, including his cousin George Cadbury, his sons Walter and Harrison Barrow, his second cousin William Adlington Cadbury, and his greatnephew George Corbyn Barrow.

There remain five additional newly appearing names in Figure 4: Lawson Tait, William Henry Dixon, George Marris, James Pattison and Samuel Whitfield. These members proved to be less politically notable and active on council, though Lawson Tait ${ }^{69}$ was a remarkable individual and an immensely important and pioneering surgeon.

A number of lessons may be drawn from the voting analysis for this final period. Even as Joseph Chamberlain himself was withdrawing from Birmingham's local political scene, his political allies and associates still formed a coherent, numerous and well-integrated bloc of voters on the Birmingham town council. Further, at this time, there can no longer be found a

\footnotetext{
${ }^{68}$ BDP 3 Oct 1894

${ }^{69}$ Tait was an important surgical innovator and an unyielding general controversialist, noted for "belligerent unorthodoxy", "ruthless courage" and (wonderfully) "want of respect for age and authority remarkable even in Birmingham” (Brit. Med. Journal, 24 June 1899).
} 
similar bloc of individuals voting in such an equally co-ordinated manner as to appear as an opposition $^{70}$.

\section{Concluding Comments}

The analysis above has explored the voting data produced by the Birmingham town council over the celebrated period covering the rise and mayoralty of Joseph Chamberlain.

Calculations of the closeness of individuals' voting records and applying straightforward criteria has produced a series of graphical images reflecting the way that the group connected with Chamberlain grew and developed and how the group most actively opposed to Chamberlain gradually declined.

Strikingly, the results show a progression of images showing the emergence of a consistent and coherent voting bloc of council members interpretable as Chamberlain's allies. This bloc contains, alongside Chamberlain himself, the names of some members we would expect from histories and biographies of the time to be his allies and supporters of his policies: it would have been unnerving not to see names like Baker, Dixon, Kenrick and Martineau within this group, so their presence is reassuring. But the method has also identified less celebrated individual members who were centrally important to the Chamberlain group: James Deykin, Henry Horne Ellaway, Henry Manton, William Perkins, William Shammon, Brooke Smith and William White. These individuals were crucial supporters of the cause, but they have not appeared prominently in the historical narrative. Others too have also been able to be identified within the grouping, who lent consistent if more obscure and fleeting support (perhaps, minimally, only contributing their vote), such as Alfred Arculus and Arthur Holden. By contrast, the analysis has also identified, alongside John Sadler and William Brinsley, the fiercest opponents of the Chamberlain group such as John Cornforth, John Thomason and

\footnotetext{
${ }^{70}$ Brinsley, Thomason and Taylor were still council members but Sadler, Cornforth, Lowe and Carter had retired.
} 
Joseph Taylor. These were no light-weight collection but included long-standing councillors as well as powerful mayors and aldermen. The analysis also shows how this opposition group, with its roots in the earlier, and increasingly unfashionable, Liberal-economist era on Birmingham town council, gradually dissipated and disappeared up to 1880 . Further, but necessarily very brief, information on members mentioned are contained in the Appendix below.

By 1880, the dominance of the Chamberlain Liberals within the Birmingham council might have seemed to be complete. But if the Chamberlain Liberals believed they were to be permanent victors who would retain hegemonic control of Birmingham into the future, they would be quickly and thoroughly disillusioned. As early as the mid-1880s, the bitter ideological and parliamentary-level split between (Gladstonian) Liberals and the break-away (Chamberlainite) Liberal Unionists, rooted in attitudes towards Empire and Irish Home Rule, began to reach all the way down to Birmingham's street politics and the Birmingham Liberal Caucus. Reflecting the Liberal split and the new institutionalisation of "party" on the town council, no longer did any single group dominate there and in November 1890, the Birmingham Daily Post ${ }^{71}$ reported the structure of the council as: twenty-five Liberal Unionists; twenty-four (Liberal) Gladstonians; and fourteen Conservatives. The make-up of Birmingham's town council had changed over this period as fundamentally as had the physical aspect of the city itself.

\footnotetext{
${ }^{71}$ BDP 3 Nov 1890.
} 


\section{Appendix: Dramatis Persona}

This table gives dates and more detail on the Birmingham Town Council members included above, and lists those considered "Cha mberlain's Friends", "Chamberlain's Foes", and the "Non-Aligned Group". Where evidence exists, religious, political label and occupational information is included. (Angl, Church of England; Bapt, Baptist; Cong, Congregationalist; Meth, Methodist; RC, Roman Catholic; Unit, Unitarian).

\section{Chamberlain's Friends}

\begin{tabular}{|c|c|c|c|c|c|c|c|}
\hline Name & Dates & Town Council & Belief & $\begin{array}{l}\text { Political } \\
\text { Label }\end{array}$ & Occupation & Notes & See Figures \\
\hline Arculus, Alfred & $1825-75$ & Council 1873-75 & & Liberal & $\begin{array}{l}\text { Glass maker } \\
\text { Alfred Arculus \& Co }\end{array}$ & $\begin{array}{l}\text { Decorative glass maker of lamps } \\
\text { and paperweights }\end{array}$ & 3 \\
\hline Avery, Thomas & 1813-94 & $\begin{array}{l}\text { Council 1862-92 } \\
\text { Alderman 1868-92 } \\
\text { Mayor } 1867, \\
18867 / 8,1881 / 2\end{array}$ & Cong. & Conservative & $\begin{array}{l}\text { Weighing machines } \\
W \text { and } T \text { Avery }\end{array}$ & $\begin{array}{l}\text { President, Birmingham Chess } \\
\text { Club World-class chess player, } \\
\text { drew games with Morphy, } \\
\text { Staunton and Steinitz. }\end{array}$ & \\
\hline Baker, George & $1825-1910$ & $\begin{array}{l}\text { Council 1867-1910, } \\
\text { Alderman 1874-1910 } \\
\text { Mayor 1876/7 }\end{array}$ & Quaker & Liberal & $\begin{array}{l}\text { Blacking manufacture } \\
\text { Edward Baker \& Sons }\end{array}$ & $\begin{array}{l}\text { "Baker's Blacking Recommends } \\
\text { Itself". Followed J Chamberlain } \\
\text { as Mayor. Brother to JE Baker. } \\
\text { Gladstonian Liberal. Temperance. }\end{array}$ & $2,3,4$ \\
\hline $\begin{array}{l}\text { Baker, John } \\
\text { Edward }\end{array}$ & $1828-1908$ & Council 1872-82. & Quaker & Liberal & $\begin{array}{l}\text { Blacking manufacturer } \\
\text { Edward Baker \& Sons }\end{array}$ & $\begin{array}{l}\text { Brother to G Baker. Temperance. } \\
\text { Publicans refused to rent him } \\
\text { rooms for celebrations for his } \\
\text { election }\end{array}$ & 3,4 \\
\hline $\begin{array}{l}\text { Barratt, (Dr) } \\
\text { Alfred }\end{array}$ & $1829-1909$ & $\begin{array}{l}\text { Council 1870-1909, } \\
\text { Alderman 1886-1909 }\end{array}$ & & $\begin{array}{l}\text { Liberal } \\
\text { Lib Unionist }\end{array}$ & Physician & $\begin{array}{l}\text { "Among the avant-garde of the } \\
\text { victorious party" (Hennock, p114) }\end{array}$ & 3 \\
\hline $\begin{array}{l}\text { Barrow, Richard } \\
\text { Cadbury }\end{array}$ & $1827-94$ & $\begin{array}{l}\text { Council 1871-94 } \\
\text { Alderman 1878-94 } \\
\text { Mayor } 1888 / 9\end{array}$ & Quaker & Liberal & $\begin{array}{l}\text { Tea dealer \& merchant } \\
\text { Barrow's Stores }\end{array}$ & $\begin{array}{l}\text { The "Fortnum \& Mason" of } \\
\text { Birmingham. Cadbury family } \\
\text { Remained Gladstonian Liberal }\end{array}$ & 4 \\
\hline $\begin{array}{l}\text { Chamberlain, } \\
\text { Arthur }\end{array}$ & $1842-1913$ & Council 1872-75 & Unit. & Liberal & $\begin{array}{l}\text { Industrialist } \\
\text { Smith \& Chamberlain. } \\
\text { Chamberlain \& Hookham, } \\
\text { Kynock }\end{array}$ & $\begin{array}{l}\text { Brother of Joseph. } \\
\text { Married Louis a Kenrick (1847- } \\
\text { 92, sister of William Kenrick). } \\
\text { Opposed protectionist tariff policy }\end{array}$ & 2,3 \\
\hline $\begin{array}{l}\text { Chamberlain, } \\
\text { Richard }\end{array}$ & $1840-99$ & $\begin{array}{l}\text { Council } 1874-86 \\
\text { Alderman } 1880-86 \\
\text { Mayor 1879/80, } \\
1880 / 81\end{array}$ & Unit. & $\begin{array}{l}\text { Liberal } \\
\text { Lib Unionist }\end{array}$ & $\begin{array}{l}\text { Brass founder and } \\
\text { Industrialist, coal and } \\
\text { heavy industry }\end{array}$ & $\begin{array}{l}\text { Younger brother of Joseph } \\
\text { Chamberlain. MP, West Is lington } \\
\text { 1885-1892. Major force founding } \\
\text { Birmingham Museum. }\end{array}$ & 3,4 \\
\hline
\end{tabular}




\begin{tabular}{|c|c|c|c|c|c|c|c|}
\hline Collings, Jesse & $1831-1920$ & $\begin{array}{l}\text { Council 1867- } 86 \\
\text { Alderman 1875-86 } \\
\text { Mayor 1878/9 }\end{array}$ & Unit. & $\begin{array}{l}\text { Liberal } \\
\text { Lib Unionist }\end{array}$ & $\begin{array}{l}\text { Merchant/Ironmonger } \\
\text { Collings \& Wallis. }\end{array}$ & $\begin{array}{l}\text { Lifelong friend of J Chamberlain. } \\
\text { Liberal MP, Ips wich, 1880-86; } \\
\text { Lib Unionist MP, Bordesley, } \\
\text { 1886-1912. }\end{array}$ & 2,3 \\
\hline $\begin{array}{l}\text { Cook, (Sir) } \\
\text { William Thomas }\end{array}$ & $1834-1908$ & $\begin{array}{l}\text { Council 1872-1908 } \\
\text { Alderman 1882-1908 } \\
\text { Mayor 1883/4 } \\
\end{array}$ & & Liberal & $\begin{array}{l}\text { Pin/rivet maker. } \\
\text { Harrison \& Cook }\end{array}$ & $\begin{array}{l}\text { MP, Birmingham East 1885-6. } \\
\text { Knighted, 1906. Remained } \\
\text { Gladstonian Liberal }\end{array}$ & 4 \\
\hline Deykin, James & $1827-85$ & $\begin{array}{l}\text { Council 1869-85, } \\
\text { Alderman 1877-85 }\end{array}$ & Angl. & Liberal & $\begin{array}{l}\text { Buttons \& electroplating } \\
J \& W \text { Deykin, Deykin \& } \\
\text { Sons }\end{array}$ & $\begin{array}{l}\text { Accidentally drowned in Aston } \\
\text { Reservoir. Deykin Avenue, } \\
\text { Witton, likely named for him. }\end{array}$ & $2,3,4$ \\
\hline Dixon, George & $1820-98$ & $\begin{array}{l}\text { Council 1864-67 } \\
\text { Mayor 1866/7 }\end{array}$ & Angl. & $\begin{array}{l}\text { Liberal } \\
\text { Lib Unionist }\end{array}$ & $\begin{array}{l}\text { Merchant and partner } \\
\text { Rabone Bros }\end{array}$ & $\begin{array}{l}\text { Liberal MP Birmingham 1867- } \\
\text { 1876. Liberal (then Lib Unionist) } \\
\text { MP, Edgbaston, 1885-1898. } \\
\text { Director, Lloyds Bank. }\end{array}$ & 1 \\
\hline $\begin{array}{l}\text { Dixon, William } \\
\text { Henry }\end{array}$ & $1814-95$ & $\begin{array}{l}\text { Council 1876-79 } \\
\text { Council 1880-93 } \\
\end{array}$ & Angl. & $\begin{array}{l}\text { Liberal } \\
\text { Lib Unionist }\end{array}$ & Coal merchant & & 4 \\
\hline $\begin{array}{l}\text { Edwards, Charles } \\
\text { Henry }\end{array}$ & $1820-1905 ?$ & Council 1866-83 & Unit & Liberal & $\begin{array}{l}\text { Solicitor, rentier and } \\
\text { businessman }\end{array}$ & $\begin{array}{l}\text { Later bankrupt and judged as } \\
\text { "guilty of fraud within the } \\
\text { meaning of the statute" (BDP } 15 \\
\text { Jan 1887) }\end{array}$ & 2,3 \\
\hline Edwards, Samuel & $1837-1920$ & $\begin{array}{l}\text { Council 1874- } 83 \\
\text { Alderman 1883-1920 } \\
\text { Lord Mayor 1900/01 } \\
\end{array}$ & & Liberal & $\begin{array}{l}\text { Auctioneer \& estate agent } \\
\text { Edwards, Son \& Bigwood }\end{array}$ & $\begin{array}{l}\text { Bigwood still trading. Remained } \\
\text { Gladstonian Liberal }\end{array}$ & 3 \\
\hline $\begin{array}{l}\text { Ellaway, Henry } \\
\text { Horne }\end{array}$ & $1834-87$ & $\begin{array}{l}\text { Council 1870-83, } \\
\text { Alderman } 1876-83 \\
\end{array}$ & Bapt & & $\begin{array}{l}\text { Brassfounder. } \\
\text { Henry H. Ellaway }\end{array}$ & Domestic hardware maker & $2,3,4$ \\
\hline Griffiths, Thomas & $1837-1906 ?$ & Council 1869-73 & & Liberal & $\begin{array}{l}\text { Hollowware maker } \\
\text { Griffiths \& Browett }\end{array}$ & $\begin{array}{l}\text { Firm making metal teapots, } \\
\text { samovars, etc., employing } 400+\text {, } \\
\text { failed } 1890 .\end{array}$ & 2 \\
\hline Harris, William & $1827-1911$ & Council 1865-71 & Unit & Liberal & Architect/journalist & $\begin{array}{l}\text { Secretary and President, } \\
\text { Birmingham Liberal Association. } \\
\text { Remained Gladstonian Liberal } \\
\end{array}$ & \\
\hline Hawkes, Henry & $1813-91$ & $\begin{array}{l}\text { Council 1846-75 } \\
\text { Alderman 1850-75 } \\
\text { Mayor 1852/3 }\end{array}$ & Angl & $\begin{array}{l}\text { Radical, } \\
\text { Liberal, } \\
\text { Conservative }\end{array}$ & Solicitor & $\begin{array}{l}\text { Town Coroner from } 1875 . \\
\text { President, Liberal Association. } \\
\text { Conservative MP candidate, } \\
\text { South Birmingham (1884). }\end{array}$ & 2 \\
\hline Heaton, Ralph & $1827-91$ & $\begin{array}{l}\text { Council 1867-84, } \\
\text { Alderman 1876-84 }\end{array}$ & Angl & Conservative & $\begin{array}{l}\text { Industrialist } \\
\text { Ralph Heaton \& Son, } \\
\text { The Mint, Birmingham } \\
\end{array}$ & Coinage minting firm until 2000s. & 3 \\
\hline
\end{tabular}




\begin{tabular}{|c|c|c|c|c|c|c|c|}
\hline Holden, Arthur & $1836-1913$ & Council 1874-77 & Unit & $\begin{array}{l}\text { Liberal } \\
\text { Christian- } \\
\text { Socialist }\end{array}$ & $\begin{array}{l}\text { Varnish/colour maker } \\
\text { Arthur Holden \& Sons }\end{array}$ & $\begin{array}{l}\text { Spiritualist. Daughter was Edith } \\
\text { Blackwell Holden (1871-1920) of } \\
\text { The Country Diary of an } \\
\text { Edwardian Lady (1977). }\end{array}$ & 3 \\
\hline Kenrick, William & $1831-1919$ & $\begin{array}{l}\text { Council 1870-1914 } \\
\text { Alderman 1877-1914 } \\
\text { Mayor 1877/8. }\end{array}$ & Unit. & $\begin{array}{l}\text { Liberal } \\
\text { Lib Unionist }\end{array}$ & $\begin{array}{l}\text { Hardware Manufacturer } \\
\text { Archibald Kenrick \& Sons }\end{array}$ & $\begin{array}{l}\text { Married Mary Chamberlain } \\
\text { (1838-1918, J. Chamberlain's } \\
\text { sister). His sister, Harriet (1835- } \\
\text { 63) was J Chamberlain's first } \\
\text { wife. MP, North Birmingham, } \\
\text { 1885-98 }\end{array}$ & $2,3,4$ \\
\hline Manton, Henry & 1809-1903 & $\begin{array}{l}\text { Council 1852-1903 } \\
\text { Alderman 1856-1903 } \\
\text { Mayor 1861/2 }\end{array}$ & Cong & Liberal & $\begin{array}{l}\text { Silversmith/goldsmith } \\
\text { Henry Manton }\end{array}$ & $\begin{array}{l}\text { Gladstonian Liberal. Temperance. } \\
\text { Son was Sir Henry J Manton } \\
\text { (1835-1924), councillor, 1881-90 } \\
\text { and knighted, } 1912\end{array}$ & 2,3 \\
\hline Marris, George & $1829-1906$ & $\begin{array}{l}\text { Council 1875-81, } \\
\text { Council 1885-88 }\end{array}$ & Cong & Liberal & $\begin{array}{l}\text { Cabinet/Metalware maker } \\
\text { Marris \& Norton, George } \\
\text { Marris \& Son }\end{array}$ & $\begin{array}{l}\text { Chairman, Union Bank of } \\
\text { Birmingham }\end{array}$ & 4 \\
\hline $\begin{array}{l}\text { Martineau, (Sir) } \\
\text { Thomas }\end{array}$ & $1828-93$ & $\begin{array}{l}\text { Council } 1876-93 \\
\text { Alderman } 1883-93 \\
\text { Mayor } 1884 / 5 \\
1885 / 6,1886 / 7\end{array}$ & Unit & $\begin{array}{l}\text { Liberal } \\
\text { Lib Unionist }\end{array}$ & $\begin{array}{l}\text { Lawyer } \\
\text { Ryland \& Martineau }\end{array}$ & $\begin{array}{l}\text { Partner with Arthur Ryland. } \\
\text { Brother to RF Martineau. Brother- } \\
\text { in-law to J. Chamberlain. } \\
\text { Married Emily Kenrick (1838- } \\
\text { 99). Knighted } 1887 .\end{array}$ & 4 \\
\hline $\begin{array}{l}\text { Martineau, } \\
\text { Robert Francis }\end{array}$ & 1831-1909 & $\begin{array}{l}\text { Council 1874-1909 } \\
\text { Alderman 1900-1909 }\end{array}$ & Unit & Liberal & $\begin{array}{l}\text { Cockfounder, merchant, } \\
\text { publisher } \\
\text { Martineau \& Smith }\end{array}$ & $\begin{array}{l}\text { Brother of T. Martineau. Brass } \\
\text { trade publishers with Brooke } \\
\text { Smith family. Gladstonian. }\end{array}$ & 3,4 \\
\hline Parry, Peter & 1840-?? & Council 1871-76 & & Liberal & Merchant & $\begin{array}{l}\text { Little information known after } \\
1876 \text {. }\end{array}$ & 2 \\
\hline Pattis on, James & $1822-1900$ & Council $1875-81$ & Cong & Liberal & $\begin{array}{l}\text { Confectioner } \\
\text { Pattison \& Son }\end{array}$ & $\begin{array}{l}\text { Pattison \& Co Ltd produced } \\
\text { pastries and sweets locally until } \\
\text { the } 1960 \text { s }\end{array}$ & 4 \\
\hline Perkins, William & $1823 ?-93$ & Council 1866-83 & Cong & Liberal & Pawnbroker & & 3,4 \\
\hline Phillips, Thomas & 1796-1876 & $\begin{array}{l}\text { Council } 1838-76 \\
\text { Alderman } 1840-76 \\
\text { Mayor } 1844 / 5\end{array}$ & Unit & Liberal & $\begin{array}{l}\text { Wine merchant. } \\
\text { Palmer \& Phillips }\end{array}$ & $\begin{array}{l}\text { Partner to the late Alderman John } \\
\text { Palmer. Director, Birmingham } \\
\text { and Midland Bank. }\end{array}$ & 1,2 \\
\hline
\end{tabular}




\begin{tabular}{|c|c|c|c|c|c|c|c|}
\hline Ryland, Arthur & $1807-77$ & $\begin{array}{l}\text { Council } 1854-58 \\
\text { Council } 1859-74 \\
\text { Alderman } 1858 \\
\text { Alderman } 1861-74 \\
\text { Mayor } 1860 / 61\end{array}$ & Unit & Liberal & $\begin{array}{l}\text { Solicitor, } \\
\text { Ryland and Martineau }\end{array}$ & $\begin{array}{l}\text { Partner to T. Martineau. Founder } \\
\text { member, Birmingham Education } \\
\text { League (1869). Director, Lloyds } \\
\text { Bank. }\end{array}$ & 1 \\
\hline $\begin{array}{l}\text { Schnadhorst, } \\
\text { Francis }\end{array}$ & $1840-1900$ & Council 1872 & Cong & Liberal & Draper/Political Organiser & $\begin{array}{l}\text { "The Napoleon of the Caucus". } \\
\text { Secretary, National Liberal } \\
\text { Federation, 1877-92. Remained } \\
\text { Gladstonian Liberal. } \\
\end{array}$ & \\
\hline $\begin{array}{l}\text { Shammon, } \\
\text { William }\end{array}$ & $1825-94$ & $\begin{array}{l}\text { Council 1871-94, } \\
\text { Alderman 1893-94 }\end{array}$ & Angl & $\begin{array}{l}\text { Liberal } \\
\text { Lib Unionist }\end{array}$ & $\begin{array}{l}\text { Whip and saddlery maker } \\
\text { W. Shammon \& Sons }\end{array}$ & Humble agricultural background & $2,3,4$ \\
\hline Smith, Brooke & $1797-1876$ & Council $1861-76$ & Unit & Liberal & $\begin{array}{l}\text { Brass cockfounder, } \\
\text { hardware merchant } \\
\text { Martineau \& Smith }\end{array}$ & $\begin{array}{l}\text { Director, Lloyds Bank. Partner to } \\
\text { Robert Martineau (father of T and } \\
\text { RF Martineau). Son, Brooke } \\
\text { Smith Jnr (1828-1896?) was } \\
\text { partner to RF Martineau. } \\
\end{array}$ & 1,3 \\
\hline $\begin{array}{l}\text { Tait, (Robert) } \\
\text { Lawson }\end{array}$ & $1845-99$ & Council 1876-85 & & Liberal & $\begin{array}{l}\text { Surgeon (FRCS) } \\
\text { Birmingham Hospitalfor } \\
\text { Women }\end{array}$ & $\begin{array}{l}\text { Pioneer in abdominal surgery. } \\
\text { Wrote Diseases of Women (1879). } \\
\text { Gladstonian Candidate for MP } \\
\text { (1886). }\end{array}$ & 4 \\
\hline Tonks, Edmund & $1824-98$ & Council 1870-73 & & Liberal & $\begin{array}{l}\text { Brass founder } \\
\text { William Tonks \& Sons: } \\
\text { Tonks Ltd }\end{array}$ & $\begin{array}{l}\text { Noted Arts and Crafts metalwork } \\
\text { maker. Supplier to Liberty. }\end{array}$ & 2 \\
\hline Webster, John & $1800-75$ & $\begin{array}{l}\text { Council } 1843-46 \\
\text { Council } 1862-74\end{array}$ & & Liberal & $\begin{array}{l}\text { Cottons merchant } \\
\text { Messrs Webster \& Co }\end{array}$ & $\begin{array}{l}\text { Manchester warehouseman. } \\
\text { Director, Birmingham and } \\
\text { Midland Bank. Financial } \\
\text { connections with A. Ryland. }\end{array}$ & 1,2 \\
\hline $\begin{array}{l}\text { Whateley, James } \\
\text { Thomas }\end{array}$ & $1823-93$ & Council 1871-93 & $\begin{array}{l}\text { Unit } \\
\text { Bapt }\end{array}$ & $\begin{array}{l}\text { Chartist } \\
\text { Liberal }\end{array}$ & $\begin{array}{l}\text { Button manufacture } \\
\text { Whateley and Rogers }\end{array}$ & $\begin{array}{l}\text { Temperance. Director of } \\
\text { Birmingham Coffee House Co. } \\
\text { Gladstonian. Son, Oliver } \\
\text { Whateley (1861-1926) footballer } \\
\text { for Aston Villa and England } \\
\end{array}$ & 2 \\
\hline White, William & $1820-1900$ & $\begin{array}{l}\text { Council 1873-1900, } \\
\text { Alderman 1883-1900 } \\
\text { Mayor 1882/3 }\end{array}$ & Quaker & $\begin{array}{l}\text { Liberal } \\
\text { Lib Unionist }\end{array}$ & $\begin{array}{l}\text { Copperplate Printer } \\
\text { White \& Pike Ltd }\end{array}$ & $\begin{array}{l}\text { Temperance. Philanthropist.. } \\
\text { Director, Birmingham Coffee } \\
\text { House Co. }\end{array}$ & 3,4 \\
\hline
\end{tabular}




\begin{tabular}{|c|c|c|c|c|c|c|c|}
\hline $\begin{array}{l}\text { Whitfield, } \\
\text { Samuel }\end{array}$ & $1832-85$ & Council 1876-82 & Unit & Liberal & $\begin{array}{l}\text { Brass bedstead maker } \\
\text { Samuel Whitfield \& Sons }\end{array}$ & & 4 \\
\hline $\begin{array}{l}\text { Wiggin, (Sir) } \\
\text { Henry Samuel }\end{array}$ & $1824-1905$ & $\begin{array}{l}\text { Council 1861-71 } \\
\text { Alderman 1865-71 } \\
\text { Mayor 1864/65 }\end{array}$ & Angl & $\begin{array}{l}\text { Liberal } \\
\text { Lib Unionist }\end{array}$ & $\begin{array}{l}\text { Industrialist \& metal } \\
\text { s melter } \\
\text { Henry Wiggin \& Co }\end{array}$ & $\begin{array}{l}\text { Liberal (then Lib Unionist) MP, } \\
\text { East Staffs 1880-85; Lib Unionist } \\
\text { MP, Hands worth 1885-92. } \\
\text { Knighted, } 1892 .\end{array}$ & 1 \\
\hline $\begin{array}{l}\text { Williams, Joseph } \\
\text { Powell }\end{array}$ & $1840-1904$ & $\begin{array}{l}\text { Council 1877-90 } \\
\text { Alderman } 1883-90\end{array}$ & Cong & $\begin{array}{l}\text { Liberal } \\
\text { Lib Unionist }\end{array}$ & "Gentleman" & $\begin{array}{l}\text { "genius for figures". Liberal } \\
\text { (then.Lib Unionist) MP, South } \\
\text { Birmingham 1885-1904. War } \\
\text { Office } 1895-1901 .\end{array}$ & 4 \\
\hline \multicolumn{8}{|c|}{ Chamberlain's Foes } \\
\hline Aston, Thomas & $1800-82$ & $\begin{array}{l}\text { Council 1863-71, } \\
\text { Alderman 1866-71 } \\
\text { Council 1873-76 }\end{array}$ & $\mathrm{RC}$ & Liberal & $\begin{array}{l}\text { Manufacturing Jeweller } \\
\text { Thomas Aston \& Son }\end{array}$ & $\begin{array}{l}\text { "He once was young, Radical and } \\
\text { Protestant, but now he is old, } \\
\text { Conservative and Roman } \\
\text { Catholic" (BDP } 27 \text { Oct 1873). }\end{array}$ & \\
\hline Brinsley, William & $1822-1906$ & $\begin{array}{l}\text { Council } 1855-78 \\
\text { Council } 1879-93 \\
\text { Alderman } 1865-78 \\
\text { Alderman } 1893\end{array}$ & & Conservative & $\begin{array}{l}\text { Grocery trader, landlord, } \\
\text { banking and tramways } \\
\text { director }\end{array}$ & $\begin{array}{l}\text { Leading Opponent of } \\
\text { Chamberlain. }\end{array}$ & 2,3 \\
\hline Cornforth, John & $1818-88$ & $\begin{array}{l}\text { Council 1858-77 } \\
\text { Alderman 1871-77 } \\
\end{array}$ & & & $\begin{array}{l}\text { Wire mill proprietor } \\
\text { Birmingham Screw Co }\end{array}$ & Business absorbed by Nettlefolds. & $1,2,3$ \\
\hline $\begin{array}{l}\text { Cutler, John } \\
\text { Walford }\end{array}$ & $1822-71$ & $\begin{array}{l}\text { Council 1852-71 } \\
\text { Alderman 1859-71 }\end{array}$ & Angl. & & $\begin{array}{l}\text { Solicitor to Wine Trade \& } \\
\text { Retail Brewers Society }\end{array}$ & $\begin{array}{l}\text { "connected with Mr Joseph } \\
\text { Allday" and "never took a very } \\
\text { active part in political matters" } \\
\text { (BDP } 3 \text { March 1871) }\end{array}$ & \\
\hline Games on, John & $1792-1871$ & $\begin{array}{l}\text { Council 1853-65 } \\
\text { Council } 1866 \\
\text { Alderman 1859-65 } \\
\end{array}$ & & & Cabinet maker & & \\
\hline Gooch, Ephaim & $1813-83$ & Council 1866-75 & & Liberal & Master jeweller & $\begin{array}{l}\text { Fined half-a-crown for after-hours } \\
\text { drinking (BDP } 17 \text { Sept 1874). }\end{array}$ & 2 \\
\hline Goodrick, George & $1803-94$ & $\begin{array}{l}\text { Council } 1842-44 \\
\text { Council } 1849-52 \\
\text { Council } 1853-83 \\
\text { Alderman } 1864-83\end{array}$ & & Liberal & $\begin{array}{l}\text { Rope Maker } \\
\text { John Goodrick \& Son }\end{array}$ & $\begin{array}{l}\text { "staunch Liberal of the old } \\
\text { school" (BDP 17 July 1894). } \\
\text { Buried in Quaker grounds. }\end{array}$ & \\
\hline Guest, James & $1806-83$ & Council 1860-71 & & Radical & $\begin{array}{l}\text { Stationer, publisher, } \\
\text { bookseller }\end{array}$ & $\begin{array}{l}\text { A "strict economist" (BDP } 25 \text { Oct } \\
\text { 1865). Jailed for sale of } \\
\text { unstamped newspapers, } 1834 . \\
\text { (BDP 22 Jan 1883). }\end{array}$ & 2 \\
\hline
\end{tabular}




\begin{tabular}{|c|c|c|c|c|c|c|c|}
\hline Lowe, John & $1812-99$ & Council 1863-74 & & Conservative & $\begin{array}{l}\text { Ironmonger/merchant } \\
\text { Mapplebeck \& Lowe }\end{array}$ & Showrooms in the Bull Ring & 3 \\
\hline Maher, Michael & $1834-82$ & Council 1870-73 & $\mathrm{RC}$ & Liberal & Solicitor & $\begin{array}{l}\text { Son of Councillor Michael Maher } \\
\text { (Snr) (1798-1862) }\end{array}$ & 2 \\
\hline Rolas on, William & $1818-1902$ & Council 1865-74 & & Liberal & $\begin{array}{l}\text { Jeweller/Silversmith } \\
\text { Rolason Brothers }\end{array}$ & $\begin{array}{l}\text { "adopted by the Tories as their } \\
\text { candidate" (BDP Nov 1874) }\end{array}$ & \\
\hline Sadler, John & $1815-78$ & $\begin{array}{l}\text { Council 1855-77 } \\
\text { Alderman 1865-77 } \\
\text { Mayor 1871/2 }\end{array}$ & & Liberal & $\begin{array}{l}\text { Hinge manufacturer } \\
\text { Messrs Sadler \& Davis }\end{array}$ & $\begin{array}{l}\text { Leading Opponent of } \\
\text { Chamberlain. }\end{array}$ & $1,2,3$ \\
\hline Taylor, Joseph & $1817-85$ & $\begin{array}{l}\text { Council 1863-85 } \\
\text { Alderman 1871-85 } \\
\end{array}$ & & Conservative & Currier (leather tanner) & $\begin{array}{l}\text { "consistent Conservative in } \\
\text { politics" (BDP } 11 \text { Nov 1885). }\end{array}$ & 2,3 \\
\hline Thomason, John & $1811-92$ & Council 1870-92 & & $\begin{array}{l}\text { Liberal } \\
\text { Lib Unionist }\end{array}$ & $\begin{array}{l}\text { Manufacturing silversmith } \\
\text { Hilliard and Thomason }\end{array}$ & $\begin{array}{l}\text { "consistent advocate of economy" } \\
\text { (BDP } 13 \text { April 1892) }\end{array}$ & 2,3 \\
\hline Wadhams, Joseph & $1816-89$ & $\begin{array}{l}\text { Council } 1858-70 \\
\text { Council } 1871-73 \\
\end{array}$ & & Conservative & Maltster & $\begin{array}{l}\text { President, Victuallers' Trade } \\
\text { National Defence League }\end{array}$ & 2 \\
\hline
\end{tabular}

"Non-Aligned" Networks

\begin{tabular}{|c|c|c|c|c|c|c|c|}
\hline Barker, Stephen & $1821-89$ & Council 1867-86 & Angl. & Liberal & $\begin{array}{l}\text { Nickel-silver metals } \\
\text { Barker and Allen Ltd; } \\
\text { Muntz Metal Co }\end{array}$ & $\begin{array}{l}\text { Major industrialist in metals and } \\
\text { coal. Land owner. Supported } \\
\text { Chamberlain's mayoralty. }\end{array}$ & 2,3 \\
\hline Carter, John & $1810-1905$ & Council 1851-78 & & Liberal & $\begin{array}{l}\text { Canal boat builder } \\
\text { Birmingham \& Midland } \\
\text { Boat Building Co }\end{array}$ & Died in New Zealand, aged 95. & 3 \\
\hline Hinks, John & $1811-85$ & $\begin{array}{l}\text { Council 1847-56 } \\
\text { Council } 1865-79\end{array}$ & & Liberal & $\begin{array}{l}\text { Steel pen maker } \\
\text { Hinks \& Wells }\end{array}$ & $\begin{array}{l}\text { Friend to Rev.George Dawson. } \\
\text { Made over a million gross pen } \\
\text { nibs pa. }\end{array}$ & 1,2 \\
\hline $\begin{array}{l}\text { Osborne, Edward } \\
\text { Corn }\end{array}$ & $1809-86$ & $\begin{array}{l}\text { Council 1856-82 } \\
\text { Alderman } 1861-82\end{array}$ & & Liberal & $\begin{array}{l}\text { Stationer, books eller \& } \\
\text { printer } \\
\text { Osborne's Stationers } \\
\end{array}$ & $\begin{array}{l}\text { Irish-born. Osborne's Stationers, } \\
\text { with } 20 \text { local shops went into } \\
\text { administration, } 2013 .\end{array}$ & 2,3 \\
\hline Prime, Thomas & $1797-1881$ & $\begin{array}{l}\text { Council 1843-48 } \\
\text { Council 1849-77 } \\
\text { Alderman 1870-77 } \\
\text { Mayor 1869/70 }\end{array}$ & Meth & Liberal & $\begin{array}{l}\text { Silversmith \& } \\
\text { Electroplater } \\
\text { Thomas Prime \& Son }\end{array}$ & $\begin{array}{l}\text { Ex-Allday-economist: "careful of } \\
\text { the interests of the ratepayer" } \\
\text { (BDP } 20 \text { Dec 1877) }\end{array}$ & 1,2 \\
\hline Sarsons, Henry & $1826-87$ & Council 1871-83 & Meth & & $\begin{array}{l}\text { Glassmaker } \\
\text { Henry Sarsons \& Son }\end{array}$ & $\begin{array}{l}\text { Major Birmingham maker of } \\
\text { fancy glass. }\end{array}$ & 2,3 \\
\hline
\end{tabular}

